\title{
Anson Unit
}

National Cancer Institute

\section{Source}

National Cancer Institute. Anson Unit. NCI Thesaurus. Code C122201.

A unit of enzyme concentration which is defined as the amount of enzyme that can digest urea-denatured hemoglobin at the same initial rate as one milliequivalent of tyrosine at standard conditions ( $25 \mathrm{C}$ and $\mathrm{pH} 7.50)$. 